\title{
Mapping accessibility for earthquake hazard response in the historic urban centre of Bucharest
}

\author{
Cristina Merciu ${ }^{1}$, Ioan Ianos ${ }^{1}$, George-Laurenţiu Merciu ${ }^{2}$, Roy Jones $^{3}$, and George Pomeroy ${ }^{4}$ \\ ${ }^{1}$ Interdisciplinary Centre of Advanced Research on Territorial Dynamics, University of Bucharest, \\ Blvd. Regina Elisabeta, 4-12, Bucharest, Romania \\ ${ }^{2}$ Faculty of Geography, University of Bucharest, Blvd. Nicolae Bălcescu, 1, 030018 Bucharest, Romania \\ ${ }^{3}$ Geography Discipline Group, Curtin University, Perth, Western Australia 6845, Australia \\ ${ }^{4}$ Geography - Earth Science Department, Shippensburg University of Pennsylvania, 1871 Old Main Drive, \\ Shippensburg, PA 17257, USA
}

Correspondence: Ioan Ianos (ianos50@yahoo.com)

Received: 19 February 2018 - Discussion started: 1 March 2018

Accepted: 26 June 2018 - Published: 25 July 2018

\begin{abstract}
Planning for post-disaster accessibility is essential for the provision of emergency and other services to protect life and property in impacted areas. Such planning is particularly important in congested historic districts where narrow streets and at-risk structures are more common and may even prevail. Indeed, a standard method of measuring accessibility, through the use of isochrones, may be particularly inappropriate in these congested historic areas. Bucharest, Romania, is a city with a core of historic buildings and narrow streets. Furthermore, Bucharest ranks second only to Istanbul among large European cities in terms of its seismic risk. This paper provides an accessibility simulation for central Bucharest using mapping and geographic information system (GIS) technologies. It hypothesizes that all buildings in the risk 1 class would collapse in an earthquake of a similar magnitude to those of 1940 and 1977. The authors then simulate accessibility impacts in the historic centre of Bucharest, such as the isolation of certain areas and blockages of some street sections. In this simulation, accessibility will be substantially compromised by anticipated and extensive building collapse. Therefore, policy makers and planners need to fully understand and incorporate the serious implications of this compromised accessibility when planning emergency services and disaster recovery responses.
\end{abstract}

\section{Introduction}

A longitudinal analysis of natural hazards in major urban areas shows an increasing awareness of the frequency of disasters and especially of earthquakes (Eshghi and Larson, 2008; Armaş, 2012; Lu and $\mathrm{Xu}, 2014)$. Indeed, earthquakes are among the natural disasters that generate the greatest human and material losses (Geis, 2000; Armaş and Avram, 2008; Atanasiu and Toma, 2012). Their impacts demand a prompt response from decision makers and the wider population, through the proper management of emergency situations (Waugh and Streib, 2006). In any disaster situation, one of the most important factors across all the disaster phases is public-private emergency cooperation for post-disaster accessibility and efficient intervention. By developing a model to harmonize this strong cooperation, Wiens et al. (2018) identify efficient ways to improve the logistics of these operations during crisis management.

Many areas of high seismic risk are urbanized and densely populated (Pollino et al., 2012; Vatseva et al., 2013). In addition, and coincidentally, many countries experiencing economic transitions are characterized by urban growth that is uncontrolled, and in large and medium-sized urban centres such growth can be especially chaotic (Salvati, 2014). Thus, an increase in the human and economic cost of such disasters can be reasonably anticipated. Furthermore, many new buildings; new structures; and, sometimes, newer pieces of infrastructure frequently fail to comply with the construction regulations established for areas of differing seismic vulner- 
ability, especially when there are strong pressures for rapid development. Finally, the characteristically long time lags between pairs of strong earthquakes (Schweier and Markus, 2006) can dull public awareness of the potential impacts of such disasters and render those in charge of emergency management complacent.

Earthquakes require a specific disaster planning approach (Armaş, 2008; Boştenaru Dan and Armaş, 2015). This is because, unlike disasters that can be anticipated in the short term (such as storms), there is little or no delay between the occurrence of the earthquake and the subsequent loss of life and property damage. Therefore, emergency response activities must be executed very quickly and efficiently (Wegscheider et al., 2013). For cities with a high earthquake risk, an important factor is public awareness of such events. This conditions the population towards the importance of quick response measures, which can help to reduce property damage and, more importantly, the number of casualties (Armaş and Avram, 2008). However, no matter how well organized the mitigation process, the disastrous effects of major earthquakes cannot be totally avoided (Momani and Salmi, 2012).

Post-disaster recovery needs to transfer the most debated academic concepts (disaster resilience, for example) into appropriate politics and transform them into real tools for adequate planning. Governments have an important task: to prepare the population and all stakeholders for future similar events (Comerio, 2014).

In recent years, seismic risk management has been more fully studied and developed so as to establish a series of priorities related to the rehabilitation of those buildings considered to be of major importance, including schools (Grant et al., 2007; Raffaelle et al., 2013; Panahi et al., 2013), public institutions, historic buildings, and monuments (Grasso and Maugeri, 2009; Pessina and Meroni, 2009). Urban earthquake planning therefore needs to be more proactive (Boştenaru Dan et al., 2014), and there is a demonstrated requirement for coherent urban policies (Ianos et al., 2017) to mitigate the inevitable occurrence of blockage points during emergency interventions.

In emergency situations, the key response element is rapid accessibility to places where possible casualties may be located. Timely intervention within the first $2 \mathrm{~h}$ is critical in saving the wounded and in identifying the safest access routes for specific emergency equipment. As Fiedrich (2007) suggests, the disaster responses made during the first 3 days are fundamental. After that, the main goals are invariably rescuing trapped victims and treatment of the injured, though ongoing fire control may also be required in some cases.

In general, natural hazard management includes the development of impact scenarios before the actual disasters occur (Bakillah et al., 2013). In this context, geographic information systems (GIS) techniques may be particularly useful in developing decision-making and response scenarios for potential earthquake disasters.
Our study shows that special attention should be paid to accessibility in the historic centres of large cities (Ianos and Cepoiu, 2009). Historic city centres are characterized by intense pedestrian traffic and by a high proportion of attraction points (clubs, restaurants, hotels, etc.) which result in high concentrations of people. Since the core of the historic centre of Bucharest is characterized by a high number of buildings that were strongly affected by earthquakes in the last century, we can reasonably speculate that determining their accessibility in an emergency situation will facilitate quick intervention in areas where injured people - either direct casualties or victims of earthquake-related phenomena such as fires, gas accumulations, or local flooding - are likely to be concentrated. The main objective of the study is to integrate geospatial data using thematic mapping products with GIS techniques in order to provide seismic risk management solutions for Bucharest. We therefore seek to provide concrete data and comprehensible information that can enable decision makers to implement and prioritize their disaster management strategies. A similar study, based on different hazard scenarios and a deep analysis on social vulnerability in Bucharest, identifies the importance of fire stations, hospitals, and parks in post-disaster situations (Armaş et al., 2016).

Unlike most studies of community response following an earthquake occurrence and the critical analysis of the emergency situations management generated thereby (Pollino et al., 2012; Wegscheider et al., 2013; $\mathrm{Lu}$ and $\mathrm{Xu}, 2014$ ), the present study demonstrates the importance of GIS analyses in detecting potential congestion and inaccessibility issues in areas where buildings are most likely to collapse and accessibility issues are most likely to arise as a result of an earthquake.

\section{Case study}

Bucharest is Romania's largest city (with over 2 million inhabitants), the national capital, and one of the great metropoles of southeastern Europe (GROSEE Espon Project, 2014). Its urban evolution has been very rapid, largely occurring from the second half of the 19th century. Currently, the city occupies an area of $228 \mathrm{~km}^{2}$ and possesses a housing stock predominantly consisting of multifamily apartment buildings, built during the communist period (Ianos et al., 2016). Located about $135 \mathrm{~km}$ from the epicentre of the Vrancea seismic area (Lungu et al., 2000), in close proximity to the Southern Carpathian Mountains and at the junction of the Eastern European, Intra-Alpine, and Moesia plates (Mărmureanu et al., 2011), the city is extremely vulnerable to earthquakes. Indeed, in a classification of European metropolitan areas with respect to potential loss of life and damage to property, Bucharest is ranked second after Istanbul (Bala, 2014).

The historical record of Bucharest is replete with accounts of damaging earthquakes ever since the city's founding (Tat- 


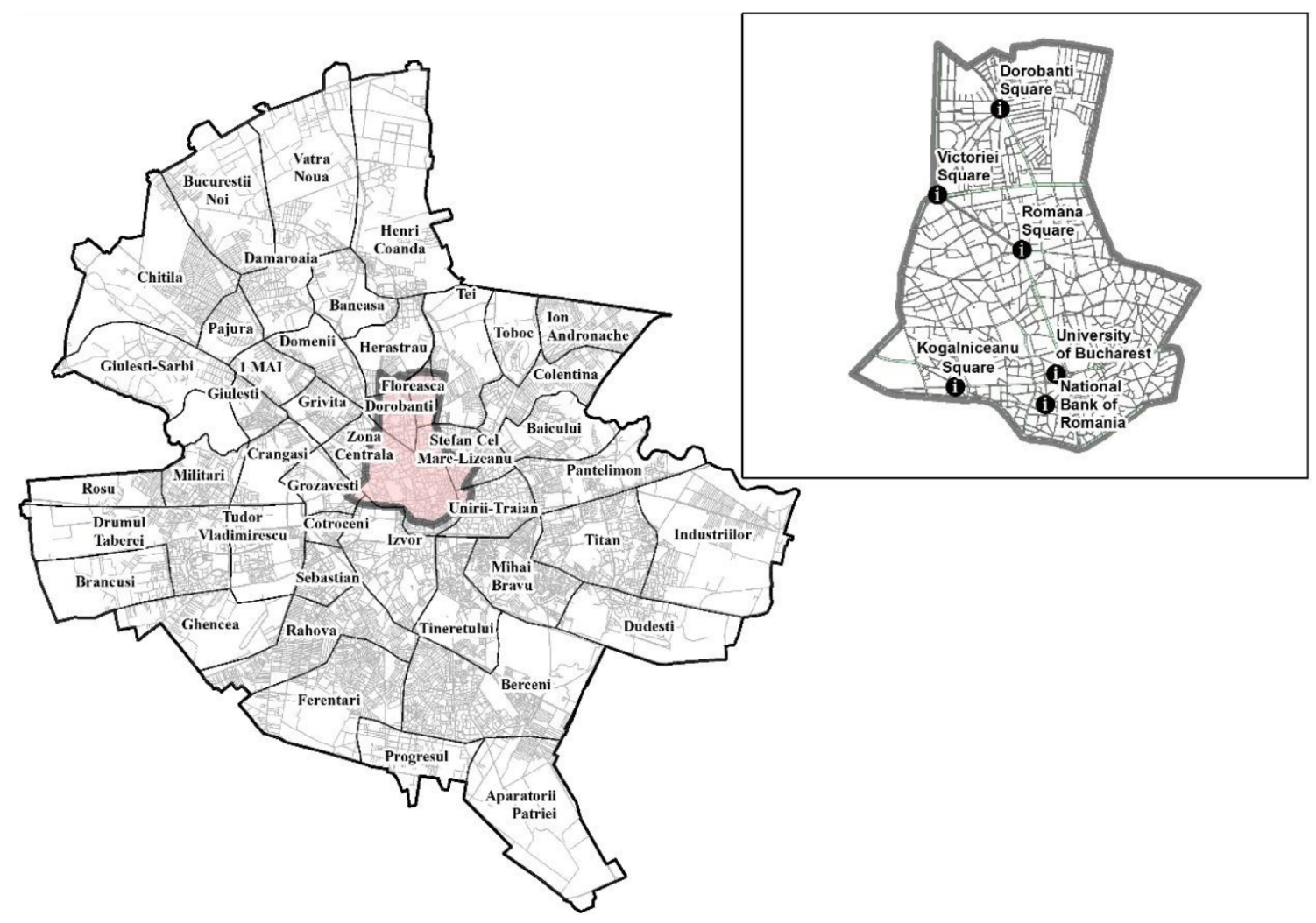

Figure 1. The city of Bucharest and its surrounds.

evossian and Albini, 2010). The Vrancea seismic area is responsible for the highest seismic risk in Romania (Pavel et al., 2014; Ardeleanu et al., 2005). Over the past 76 years, Bucharest has been affected by four earthquakes with a magnitude of between 6.9 and 7.7 on the Richter scale (November 1940, March 1977, August 1986, and May 1990).

The study area for this paper is confined to central Bucharest, an area of approximately $8.33 \mathrm{~km}^{2}$ (Fig. 1). The oldest part of the city is situated in the south of this area, which comprises the historic centre (from the 16th and 17th centuries) and the central and northern parts dating from the 18th and 19th centuries. All four earthquakes mentioned above have impacted this case study area, with the most powerful being the earthquakes of 1940 and 1977. This sequence of earthquakes has had a cumulative effect, which explains the relative lack of buildings dating back more than 200 years.

The most serious problem is presented by the large number of buildings from the late 19th century within the historic centre, which has structurally degenerated over time and no longer meets the current building standards with regard to assessment of the ground motion levels for the Vrancea (Romania). Not only does Bucharest have a high level of exposure to earthquake hazards; it also suffers from poorly organized civil protection services and a low level of public awareness and education concerning these seismic risks (Armaş, 2006).
Nevertheless, anticipation and anxiety are building, given the length of time that has passed since the 1977 major earthquake. In essence, there is a fear that the city will be no better prepared than it was in 1940 (Fig. 2a) or in 1977 (Fig. 2b). These figures show only a slight improvement in the standard of the disaster measures between the two dates, and there is a growing recognition that greater levels of preparedness are needed.

Immediately after the earthquake of 4 March 1977, with about 1700 victims (Török, 2017), the former regime announced the start of a rehabilitation project for the highly degraded buildings within the central area, a project which was abandoned in less than a year. Many buildings, after being braced in position for 6-7 months with wooden or metal poles (which were later withdrawn), were then only "cosmeticized" and reoccupied. These decisions set a precedent for irresponsible policy that, unless it is addressed and altered, could have disastrous long-term consequences. Additionally, the growth of complacency over time has been a great enemy, and a permanent state of vigilance is needed. Finally, there is a need for considerable public investment in mitigation in the areas most vulnerable to earthquakes. The lack of wider public awareness of the high seismic risk of these buildings (identified as a result of surveys conducted in and since the mid-1990s) is evident in that the apartments in 

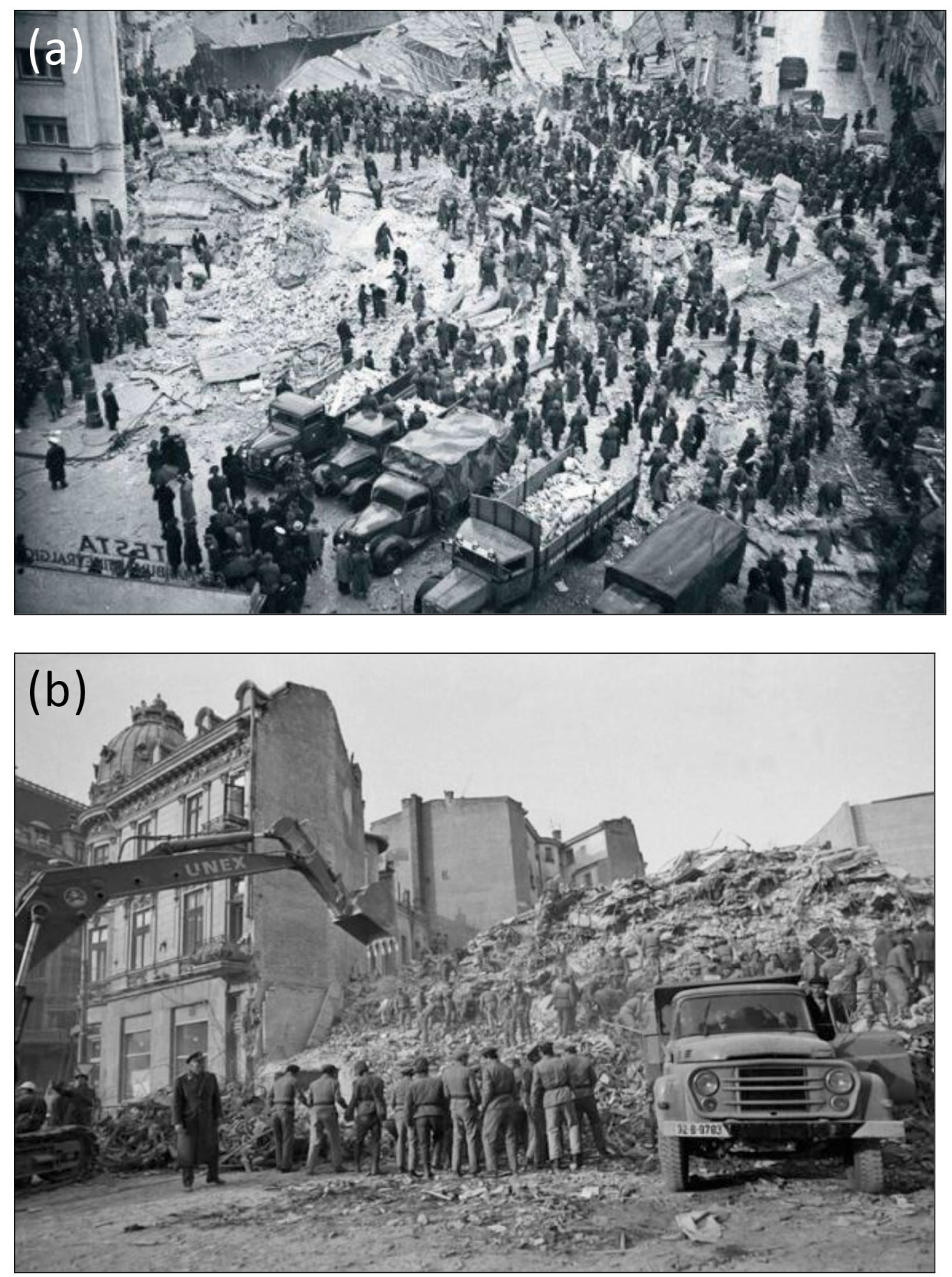

Figure 2. (a) The collapse of the Carlton block in Bucharest in 1940. Source: https://upload.wikimedia.org/wikipedia/commons/6/60/Iosif_ Berman_-_Marele_cutremur_din_anul_1940.jpg (last access: 3 June 2017). (b) The collapse of the Continental block in Bucharest's historical centre in 1977 blocked the access streets, so clearance was delayed by more than $12 \mathrm{~h}$. Source: Agerpres.

these cosmeticized blocks are still among the most expensive in the city due to their central location and spaciousness.

Accordingly, the Romanian government has established the National Committee for Emergency Situations and the
Department for Emergency Situations. The department coordinates the General Inspectorate of Emergency Situations. Forty-one local inspectorates cover the city of Bucharest and the department of Ilfov. The city of Bucharest has three exist- 
ing meeting points (two in Bucharest and other in the village of Ciolpani to the north), and there is a special strategy to bring in instantaneous support from 24 counties surrounding the city.

\section{Data and methods}

This assessment of seismic hazard and vulnerability includes quantitative and qualitative data analysis that incorporates physical, environmental, social, and economic factors; potential impacts from existing risk maps; and estimates of the population that would potentially be affected (Mândrescu, 1990; Armaş, 2012; Rufat, 2013; Pollino et al., 2012). The accessibility analysis takes into consideration the specificities of each urban district, especially the urban context (Noto, 2017).

\subsection{Data}

The authors have used several data sets (buildings classified by seismic risk and emergency categories, i.e. the presence of hospitals and fire stations) in order to provide a realistic depiction of the impact that a potential earthquake could have in the historical centre of Bucharest. Only those fire stations and hospitals within the municipal limits of Bucharest are included. The main data sources were provided by public institutions. Every year the municipality of Bucharest publishes a technical report classifying buildings with relation to four seismic risk criteria and three emergency criteria to assess their level of public safety. Table 1 shows the distribution of Bucharest's buildings by risk and emergency categories. Special attention is paid to the historic centre of Bucharest, which contains the largest concentration of buildings which represent a public safety risk.

To represent the accessibility patterns prior and subsequent to an earthquake, it was necessary to digitize all elements of the transport infrastructure, construction, green spaces, alleys, sidewalks, and property limits.

Several different map sources were used to identify building locations, including cadastral maps at scales of $1: 500$ and 1:2000 (IGFCOT, 1974-1975). Other map types and sources include old maps of Bucharest produced by the Topographic Military Directorate and orthophotomaps (2014) taken from the National Agency for Cadastre and Real Estate Advertising. The authors have overlaid accessibility patterns on a numerical model of the land, given the absence of natural barriers, since the municipality of Bucharest is located on a plain.

\subsection{Methods}

An important methodological contribution on the capacity of a city to resume urban functions after a seismic event is the study by Goretti et al. (2014) on how the Crotone urban system could better respond to such disasters. This study shows the importance of rapid accessibility to collapsed buildings and to injured people. Our study therefore emphasizes the importance of immediate accessibility for emergency intervention mechanisms and the need to provide information to facilitate the proactive actions of decision makers, who need clear and straightforward directions.

The main methodological steps in mapping accessibility in the central area of Bucharest were (a) setting up a reference database of all the buildings with seismic risk; (b) transferring this information to a detailed map of the identified buildings; (c) identifying indicators of building density and age, and traffic (including pedestrian) intensity; (d) showing the locations of all hospitals and fire stations; (e) calculating present-day (before a possible earthquake) accessibility levels; (f) identifying specific locations of potential congestion resulting from the collapse of buildings included in the highest risk class; and ( $\mathrm{g}$ ) determining, by simulation, the immediately inaccessible or poorly accessible areas for the intervention crews in the case of an earthquake, taking into account those buildings that might collapse if an earthquake occurs.

In the scientific literature, "access" is mainly measured as a physical distance or travelling time (Sotoudehnia and Comber, 2011). In this study, mapping the accessibility of the central area of Bucharest was completed using GIS techniques incorporating spatial analysis. The calculation of accessibility was initially based on the geometric structure of the public transport network (busses, trams, and underground services), but not on the walking and cycling networks, which, although they have been included in other studies, are less amenable to emergency service access in this context (Graeme and Aylward, 1999; Parker and Campbell, 1998; Naphtali, 2006; Svensson, 2010; Weiping and Chi, 2011; Sotoudehnia and Comber, 2011; ESPON TRACC Interim Report, 2011; ESPON GROSEE Final Report - Scientific Report, 2014; Blandford et al., 2012; Coffee et al., 2012; Yiannakoulias et al., 2013; Vojnovic et al., 2014).

The Kernel Density tool was used to calculate the density of point and line features in a neighbourhood around those networks. After modelling the road network using the ArcGIS Network Analyst extension, the authors used an assortment of analytical tools. These included the New Route tool to check the road network, the New Closest option to determine the closest emergency facility (hospital, fire station) to each point, and the New OD matrix function to determine optimal routes (depending on road distance and travel time) following the principle of the shortest possible route to establish links between each pair of points.

To highlight accessibility in the most comprehensive way, the street structure (which is very dense in the historic centre where the streets are narrow) and road traffic density had to be taken into account. Accessibility was calculated as a function of the distances between different buildings areas and hospitals and of the time necessary for these movements (using isochrones). Isochrones maps, showing travel times by 
Table 1. Building condition data for the historic centre of Bucharest (number of restored buildings is at the historical centre level; number of fire stations and hospitals is at the municipality level). RI-RIV: seismic risk categories; U1-U3: emergency categories.

\begin{tabular}{|c|c|c|c|c|c|c|c|c|}
\hline & R I & R II & R III & R IV & $\mathrm{U} 1$ & $\mathrm{U} 2$ & $\mathrm{U} 3$ & Total \\
\hline Buildings with seismic risk in Bucharest & 343 & 344 & 97 & 7 & 309 & 615 & 650 & 2365 \\
\hline $\begin{array}{l}\text { Buildings with seismic risk in the historical } \\
\text { centre of Bucharest }\end{array}$ & 65 & 1 & 2 & 1 & 82 & 9 & 5 & 165 \\
\hline $\begin{array}{l}\text { Buildings with seismic risk in the core } \\
\text { of the historical centre of Bucharest }\end{array}$ & 50 & & 1 & 1 & 41 & 2 & 2 & 97 \\
\hline $\begin{array}{l}\text { Number of buildings restored to an } \\
\text { adequate seismic standard }\end{array}$ & \multicolumn{8}{|c|}{17} \\
\hline Fire Stations & \multicolumn{8}{|c|}{13} \\
\hline Hospitals & \multicolumn{8}{|c|}{32} \\
\hline
\end{tabular}

Source: processed data using the list of buildings with seismic risk, published by the municipality of Bucharest

(http://amccrs.pmb.ro/docs/Lista_imobilelor_expertizate.pdf, last access: 15 October 2017).

public transport from the city centre, had been used to assist in urban transport planning in the 1950s (Kok, 1951, Rowe, 1953 quoted by O'Sullivan, et al., 2000). These isochrones were generated using GIS.

In addition, the Kriging kernel interpolation calculation and local polynomial interpolation were used. For exact interpolation, the inverse distance weighted (IDW) method was used. These methods identified support elements for more proactive management that have the potential to bring about a decrease in both the material damage and the human casualties resulting from a strong earthquake. Using a database in a GIS environment enabled an assessment and estimation of the potential damage that could be caused by such an event. At the same time, GIS is a valuable method of analysis for this purpose because the databases can be regularly updated, allowing for ongoing mapping of the changing risk scenarios and the updating or reassessment of potential damage. The risk scenarios also provide useful identification of the vulnerable areas and population groups (Sinha et al., 2008).

The penultimate methodological step was to identify likely congestion locations. The initial simulation assumed that all the buildings categorized as possessing the highest degree of risk would collapse. For the core of the historical centre, this permitted the identification of some important sites and street segments which would be blocked in the case of a strong earthquake using the location of each highest-risk building, their age and number of floors, and the local configuration of the street network.

Our intention is not to propose a precise correlation between the vulnerability of buildings (based on all their characteristics) and the intensity of the next earthquake. Rather, especially by taking into account that some of buildings in this area have partially collapsed in the absence of a direct seismic cause, we contend that an earthquake of similar mag- nitude to the 1977 event would produce outcomes comparable to our simulation.

From this information several maps were developed taking into account the region's particular seismogenic characteristics (Mäntyniemi et al., 2003). Two offer general images of accessibility at the city level closely correlated with the territorial distribution of fire stations and hospitals. Another identifies areas or street segments potentially isolated by building collapses.

In recent years, scientific approaches to risk reduction of natural events, such as earthquakes, have used resilience as an important concept, which could offer new theoretical and practical tools for better civil protection (Fekete and Fiedrich, 2018). Using this concept, scientists are paving the way for reinvigoration of the expectations, by joint actions with decision makers and civilians (Anhorn, 2018). These ideas ask whether other complementary issues are connected with a higher accessibility to the affected areas.

Our approach, focusing on the single issue of accessibility in a situation of crisis management, shows empirically how GIS technologies can be used to make recommendations to authorities to improve their preparedness levels and response speeds in post-earthquake interventions. Within this study, GIS is used solely as a tool to identify accessibility as a starting point for disaster management (Nushi and van Loenen, 2013). These GIS solutions are demonstrably important applications in relation to the first two phases (risk mitigation and disaster preparedness) of Alexander's (2002) four-phase sequence of emergency management activities.

\section{Results}

It is necessary to simulate emergency interventions prior to the occurrence of catastrophic events because, in the local situation, the inherited intra-urban structure, with a narrow 


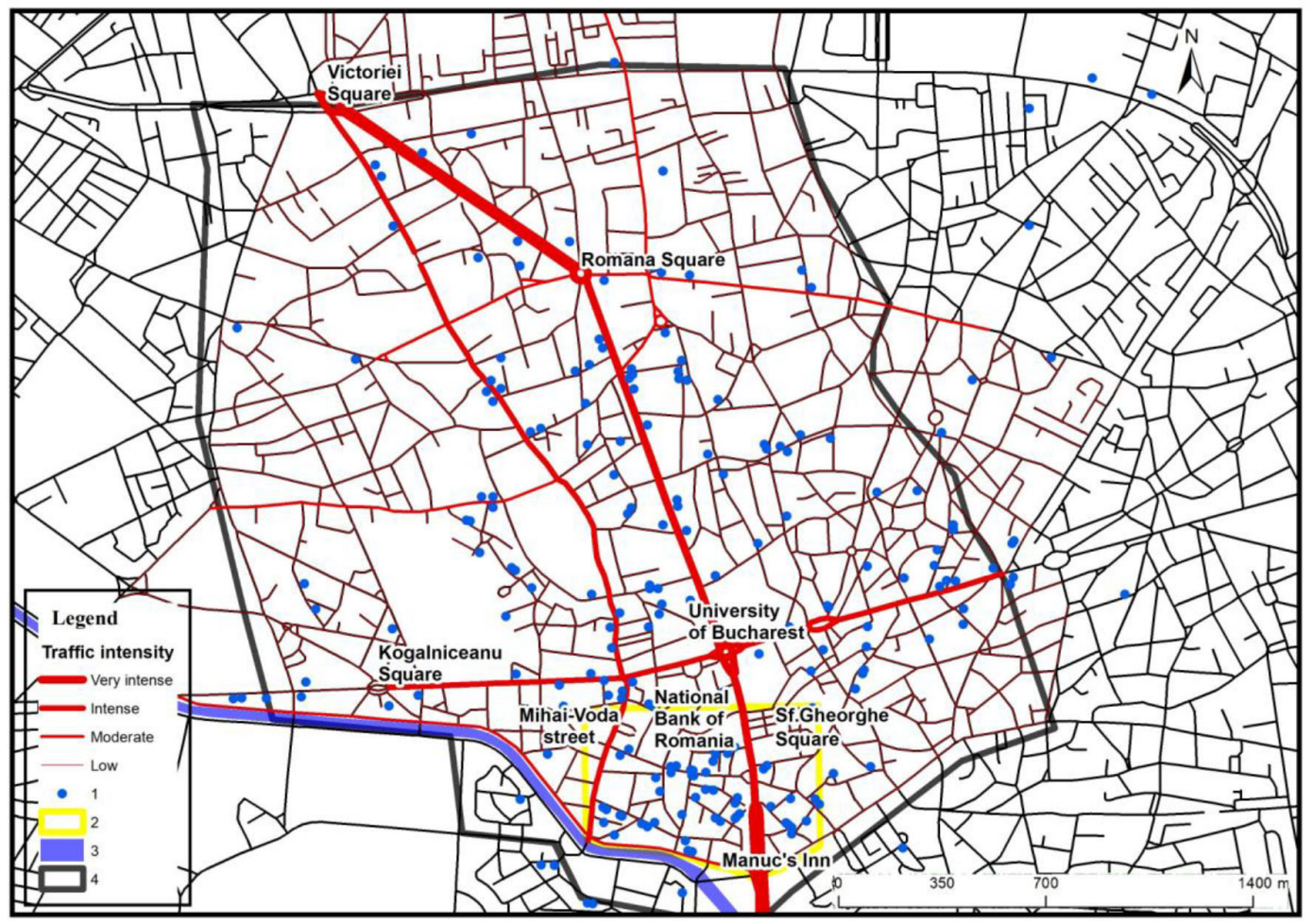

Figure 3. Road traffic intensity and the location of buildings with a high seismic risk. (1) Building; (2) core of the historic centre; (3) Dâmboviţa River; (4) study area.

winding street pattern dating back to medieval times; the poor structural condition of many of the buildings; and limited access to important points from the emergency response activity locations are all of critical importance.

In such a context, accessibility to specific disaster sites is critical, and this requires that urban areas of this nature be treated with special attention. The biggest challenge may be caused by traffic congestion compounded by debris, which can isolate critical areas, making rapid intervention to put down fires and save human lives impossible.

The official identification of buildings with a high seismic risk combined with precise mapping of their location can be related to the density of road traffic in the historic areas (Fig. 3). If traffic is very high on the main access streets, this could inhibit rapid intervention, especially in a situation of general panic such as that generated by a potential earthquake. It would also be difficult to use narrow streets, where the pedestrian traffic and partially collapsed buildings could block the access of emergency service vehicles. In this context, there is a need for proactive measures, to mitigate the risk of late arrival of assistance at the affected buildings.

The most important area of the historical centre is the one delimited by Armenească, Moşilor, and Călăraşi streets; Splaiul Independenţei; Calea Victoriei; and Carol and Regina Maria boulevards. Within this area, the building density exceeds 2.5 units ha $^{-1}$; in some places, it even exceeds
10 units ha $^{-1}$. In the areas of the highest density, most of the buildings have two or three floors, and, because of their uncertain legal status after 1990, many exhibit an advanced and increasing degree of dilapidation. Restoration and reinforcement of these buildings by both public authorities and private entrepreneurs are only proceeding at a maximum rate of two buildings per year.

The number of buildings with the highest seismic risk (computed with the Kernel Density tool) shows a very high concentration in the historical centre of Bucharest (Fig. 4). When looking at a map of seismicity at the level of Bucharest, it becomes obvious that the inherent risks from earthquake damage are greatest in central Bucharest, including the historical centre (Rufat, 2011). Even though most of the buildings located in the historical centre date from the early 20th century, they were built on the foundations of 19th-century structures (Armaş, 2008).

To highlight the anticipated degree of access for fire protection and ambulance services in the central area, accessibility levels prior to an earthquake were calculated and later compared to a post-earthquake scenario. Taking into account the location of the fire stations and hospitals, and the street tram network, the access routes into and within the study area were evaluated using the Network Analysis tool. Thus we identified the shortest routes from the closest emergency facilities (fire stations and hospitals) to all locations in the study 


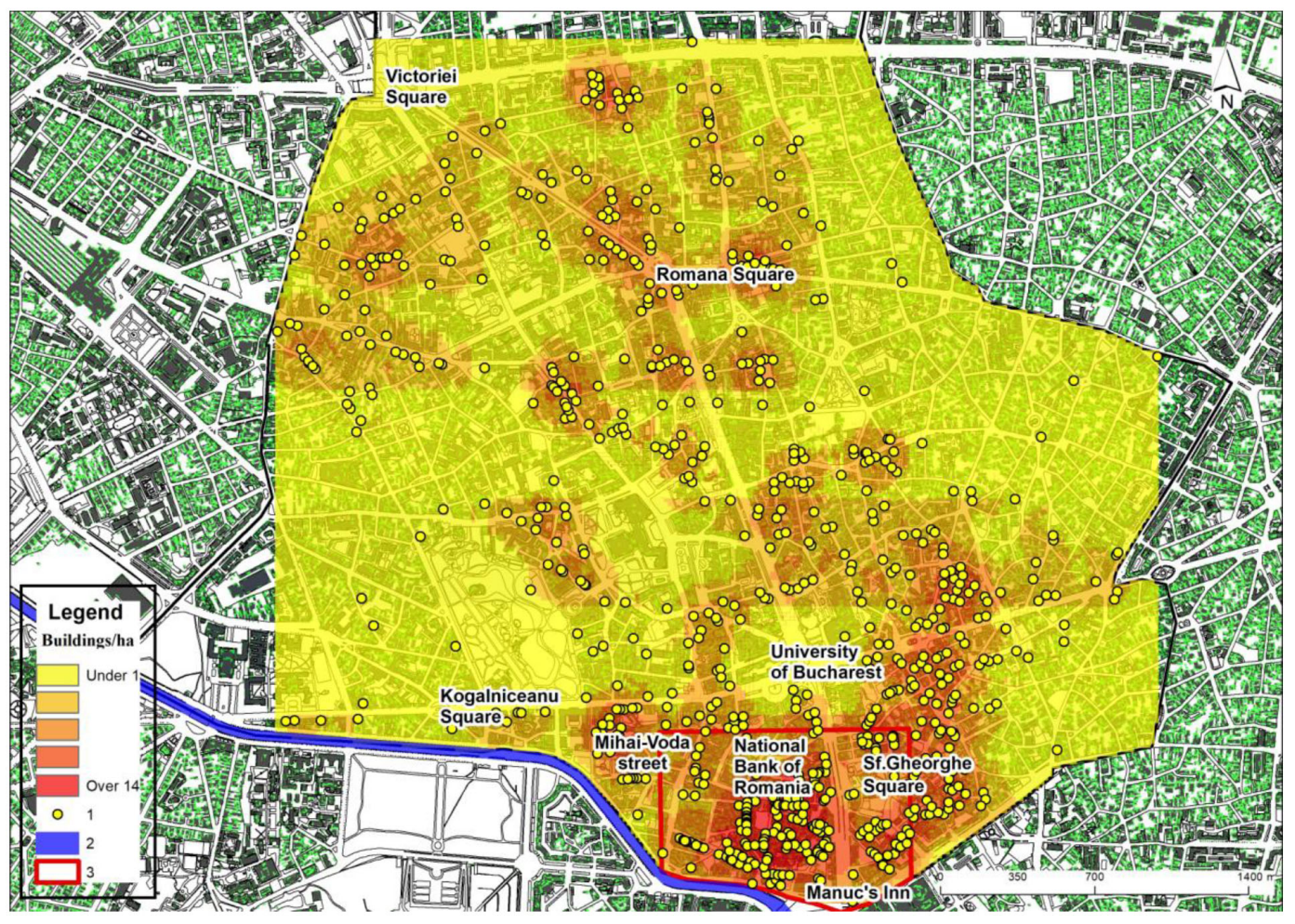

Figure 4. Density of buildings with a major seismic risk. (1) Building; (2) Dâmboviţa River; (3) core of the historic centre.

area, using the Bellman-Kalaba algorithm. These minimal road applications were applied for various types of emergency service: transport, ambulance, fire, police, etc.

It was noted that both firefighting and ambulance service accessibility were high or very high for most parts of the capital city, including the downtown area, which is especially well served by firefighter and ambulance services. There are 13 large fire stations in Bucharest. However, the lowest levels of potential accessibility by fire services to individual houses in the city of Bucharest occurred in the historic centre area, mainly due to the configuration of the street pattern (Fig. 5). The lowest values were registered in an area between Calea Victoriei, Doamnei Street, Brătianu Boulevard, and Splaiul Independenţei, in the core of the historic centre. Low values occur to the east of Brătianu Boulevard, even though some important access axes (Armenească, Calea Moşilor, Hristo Botev, Negustori) are located nearby. Overall, if fires broke out at several different points in the historic centre core during a seismic event, this would present huge problems.

The map of ambulance accessibility (Fig. 6) presents a very similar picture. However, access is better in the northern part of the historic centre due to the location of Colţea Hospital. Figure 7 shows two areas where it would be difficult for ambulances to arrive in a timely manner, one in the core of the historical centre and the other in the surrounds of Mihai Vodă Street, which would be accessed by ambulances from University Emergency Hospital.

\section{Discussion}

Should an earthquake occur, an important consideration is the challenge presented by building collapses which obstruct road access. Identifying individual buildings with the highest levels of seismic risk highlighted the possibility of concentrated building collapses in certain locations within the historic centre. In these the locations, some buildings would become isolated, and rapid intervention by fire or ambulance services would be impossible.

This general analysis indicates that the central area seems to be favoured due to the possibility of intervention from several emergency service points into this part of the city. However, and in spite of this, pedestrian and vehicular congestion is highly likely to inhibit rapid access by firefighters and ambulances in several areas within the central district. Also, several locations in the downtown area, which previously appeared to have high emergency accessibility levels, were shown to possess high probabilities of multiple building collapses. These events could well obstruct access by emergency vehicles, despite the high levels of accessibility that were identified initially.

Should an earthquake with a magnitude of over 7 on the Richter scale occur, fires would present a major associated risk. The majority of the city centre buildings are of timber construction or possess many timber components (some buildings from Şelari Street, e.g. "Crama Dom- 


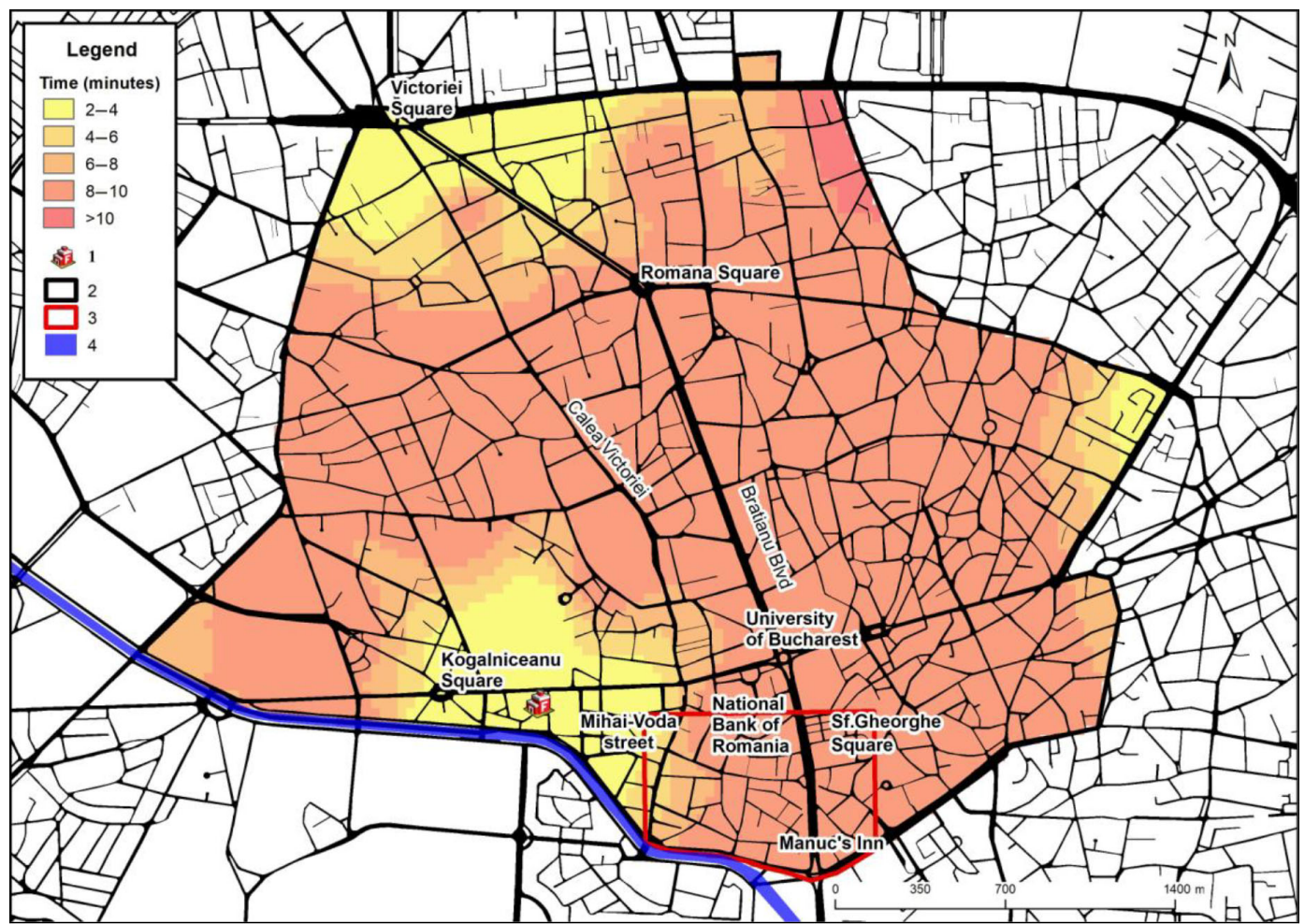

Figure 5. Firefighting accessibility levels within the study area. (1) Fire station; (2) study area; (3) core of the historic centre; (4) Dâmboviţa River.

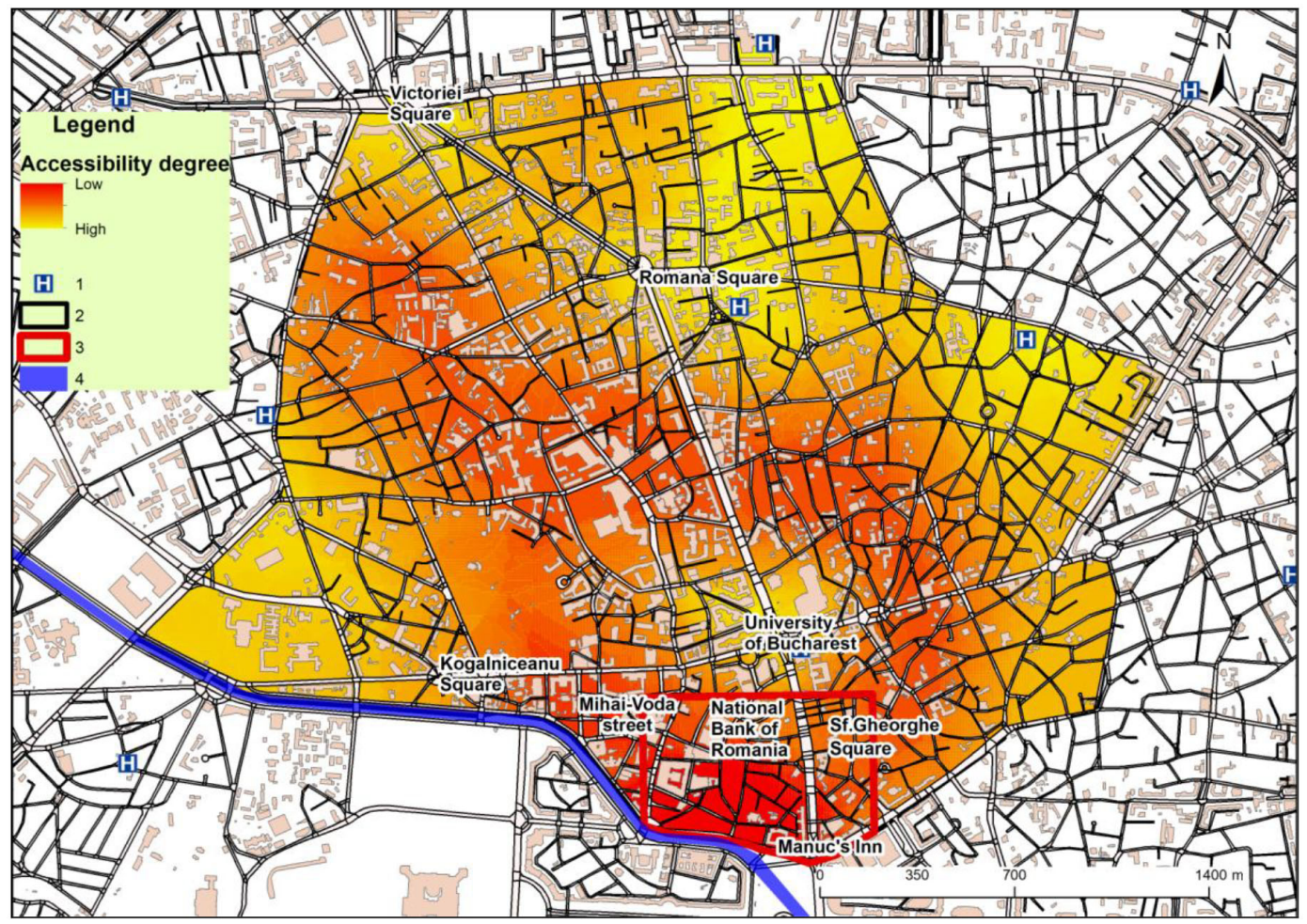

Figure 6. Ambulance accessibility levels within the study area. (1) Hospital; (2) study area; (3) core of the historic centre; (4) Dâmboviţa River. 


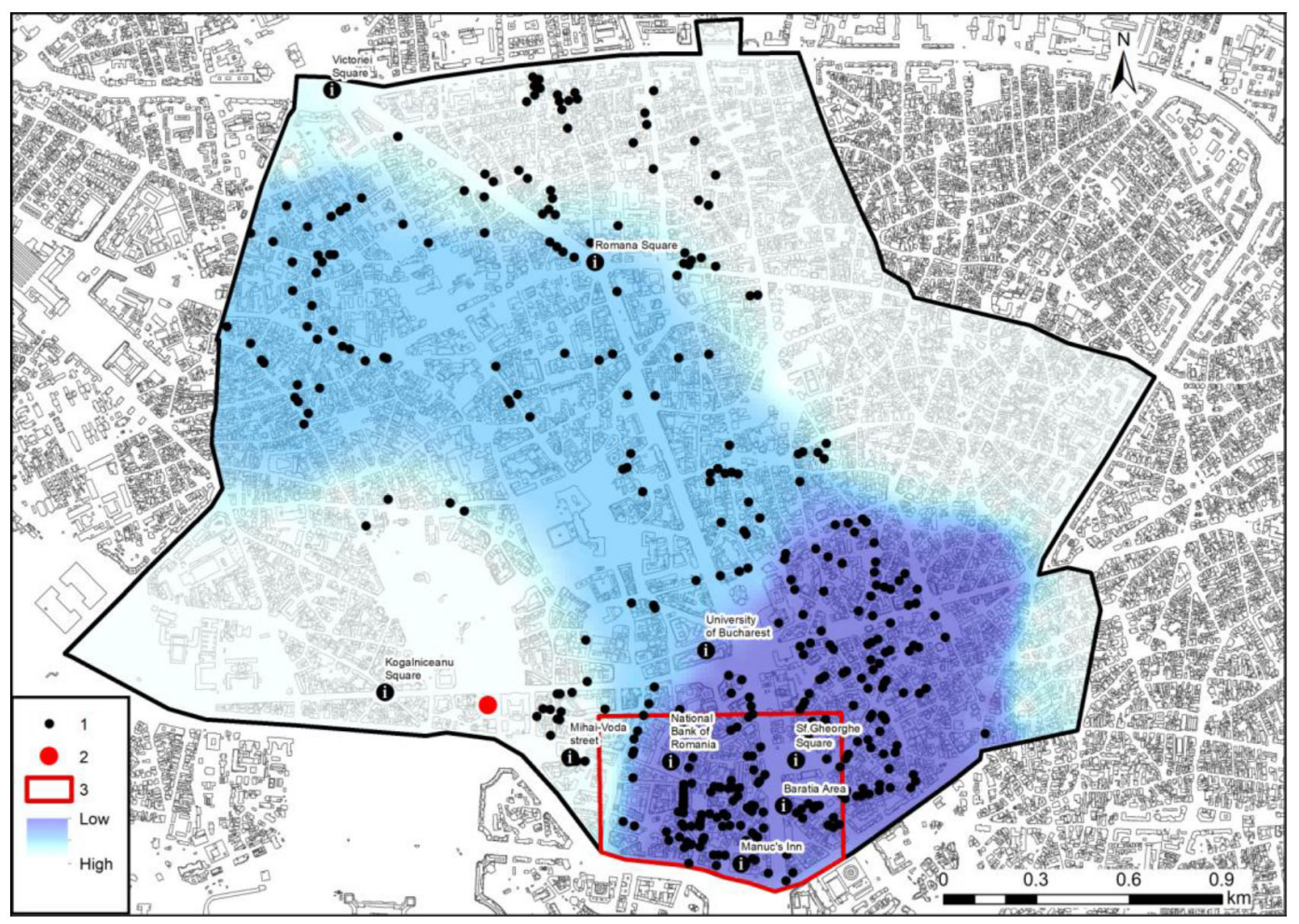

Figure 7. The accessibility of buildings with high seismic risk to firefighting services after a potential earthquake occurrence. (1) Building; (2) fire station; (3) core of the historic centre.

nească"; Covaci Street; and Smârdan Streets, for example). These buildings characteristically house restaurants, cafes, or pubs, which contain huge quantities of furniture, a further important source of fire. If emergency action does not occur promptly, in such locations, the probability of numerous fatalities is high. In addition, water supply and sewerage systems may be damaged, resulting in basement and ground floor flooding. It would therefore be advisable to provide supplementary emergency response materials at a large number of locations within this district. This would allow access to such equipment at the local scale as an alternative to the provision of emergency materials and services from elsewhere which may be unobtainable in the event of an emergency.

Assuming that, in the event of a large-scale disaster, certain clusters of buildings may become isolated and inaccessible to emergency services, it is therefore recommended that smaller-scale aid stations be established within these districts. These smaller-scale aid stations could then provide critical assistance in areas isolated by building collapses.

A detailed analysis highlights the fact that in the southwestern part of the historical center of Bucharest there is an area that includes several buildings of national importance (the parliament building, the headquarters of several ministries and other public institutions). In the proximity of this area are located several emergency services that may be oriented to ensure the protection of these public institutions, rather than the provision of services to areas with high densities of buildings with high seismic risk.

The map which shows both the distribution of the highest seismic risk buildings and the location of the nearest fire stations (Fig. 7) illustrates the need for greater proximity (and hence access) of fire stations to the two areas of maximum density of highest-risk buildings: one in the Lipscani area and the other in the Bărăţiei area. The western area (Griviţa-Gara de Nord) could be placed under the authority of the two existing fire stations. These areas of high vulnerability should be connected to a permanent emergency water supply (since the normal water sources would be disrupted by an earthquake). They should also possess a minimum, yet sufficient, level of equipment for a local first response.

The location of hospitals again appears to be favourable at first glance (Fig. 8), but their capacity should be assessed against the probable number of casualties, which could reach as high as 11000 . The earthquake of 1940 registered 1271 and the 1977 earthquake 11321 injured persons (Pavel and Văcăreanu, 2015). The location of Colţea Hospital suggests that the majority of injured persons would go there for immediate treatment. However, this hospital only possesses a small surgical unit (with three operating theatres), and it would be unable to offer emergency medical assistance to a large number of persons over a short period. 


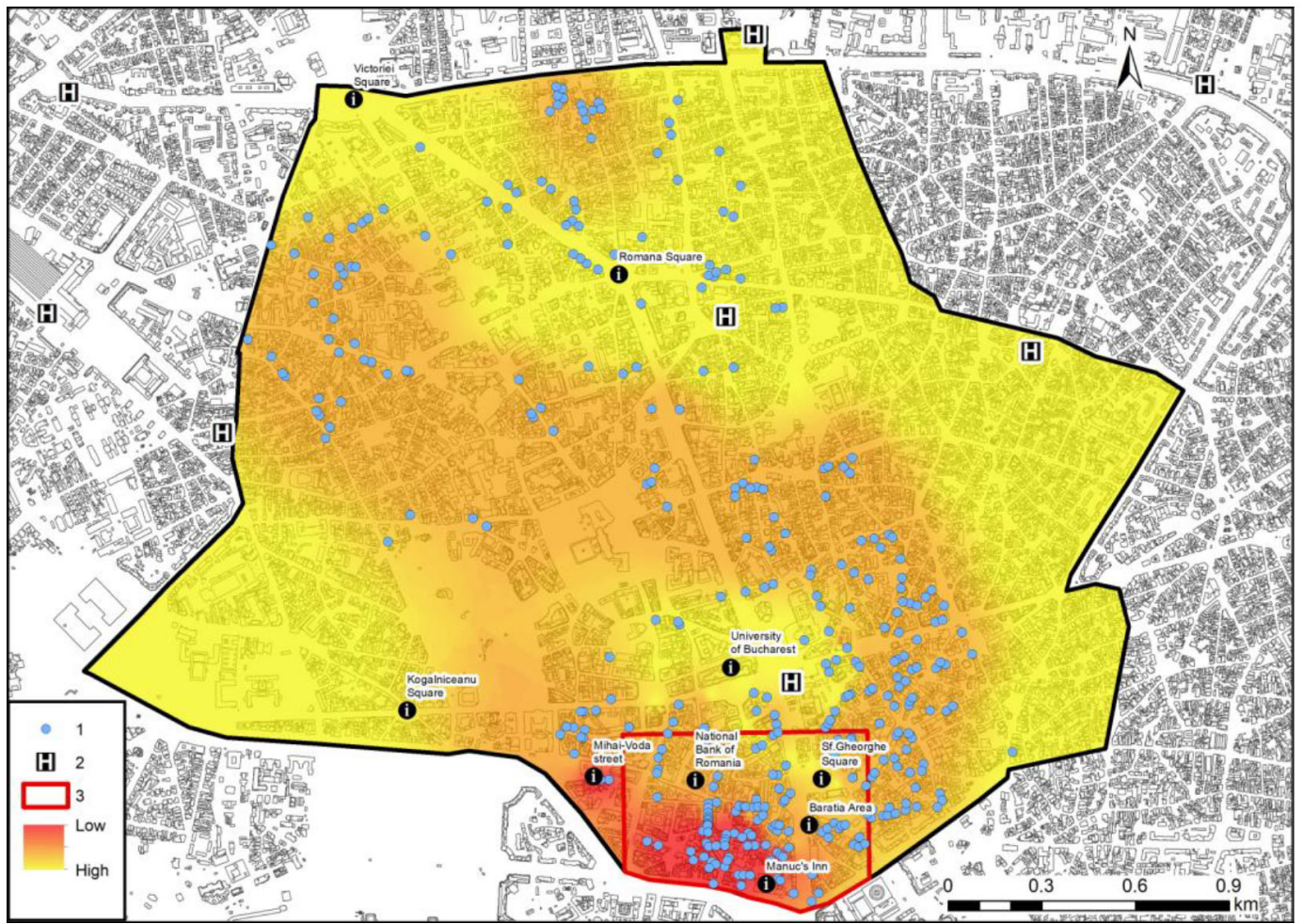

Figure 8. The territorial distribution of hospitals in the central area and their relationship to buildings with a high seismic risk. (1) Building; (2) hospital; (3) core of the historic centre.

To increase the efficiency of emergency response, the location and number of potential casualties must be more precisely determined. Consideration needs to be given to the availability of specific medical services at individual hospitals and other medical facilities. The provision of surgical wards, imaging laboratories, and orthopaedic facilities is more uneven than the provision of hospitals more generally across the city. Depending on the territorial distribution of these specific hospital services, the buildings with highest seismic risk should be assigned to specific emergency hospital services so that accessibility levels can be maximized. Obviously, this implies the designation of dynamic territorial structures, which, depending on the gravity of the reported seismic events and their human consequences, would include access to other hospitals at greater distances from the central area (Toma-Dănilă, 2013).

There are some studies on firefighting simulation outside of the historical centre of Bucharest, for example on Magheru Boulevard, which reveal the importance given to this related phenomenon with an earthquake event (Fiedrich, 2007). In the event of a powerful earthquake, a partial or even total breakdown of communication systems is likely. This eventuality would cause many people to make direct contact with friends and relatives by moving around the city by car. Rapid intervention by the traffic police would be vital to minimize congestion in those areas of the city where the need for emergency intervention is greatest.

The unpredictable nature of this phenomenon may well lead to traffic bottlenecks at unanticipated locations along the transportation network, which in turn would further complicate rescue, relief, and evacuation efforts. In these circumstances, communication systems between those who would be mapping the collapsed or damaged buildings and those who would be ensuring the traffic flow need to function as smoothly as possible in order to allow the wounded to be transported to hospitals and the fire engines to move towards critical spots in the city. Where the simultaneous collapse of buildings, especially in the medieval area of the city, made rapid intervention impossible, lifesaving equipment, individually transported by specially trained persons, would be needed to provide immediate assistance.

Our study has sought to demonstrate what could happen in the core of the historic centre (Fig. 9), taking into consideration the likely collapse of buildings classified as risk 1 (R1). Any future earthquake of more than 7.2 on the Richter scale (the level of the strongest recent earthquake on 4 March 1977) would pose an amplified danger of the collapse of buildings at critical locations. We define critical locations as those where building collapse could block access to specific areas or street segments. 


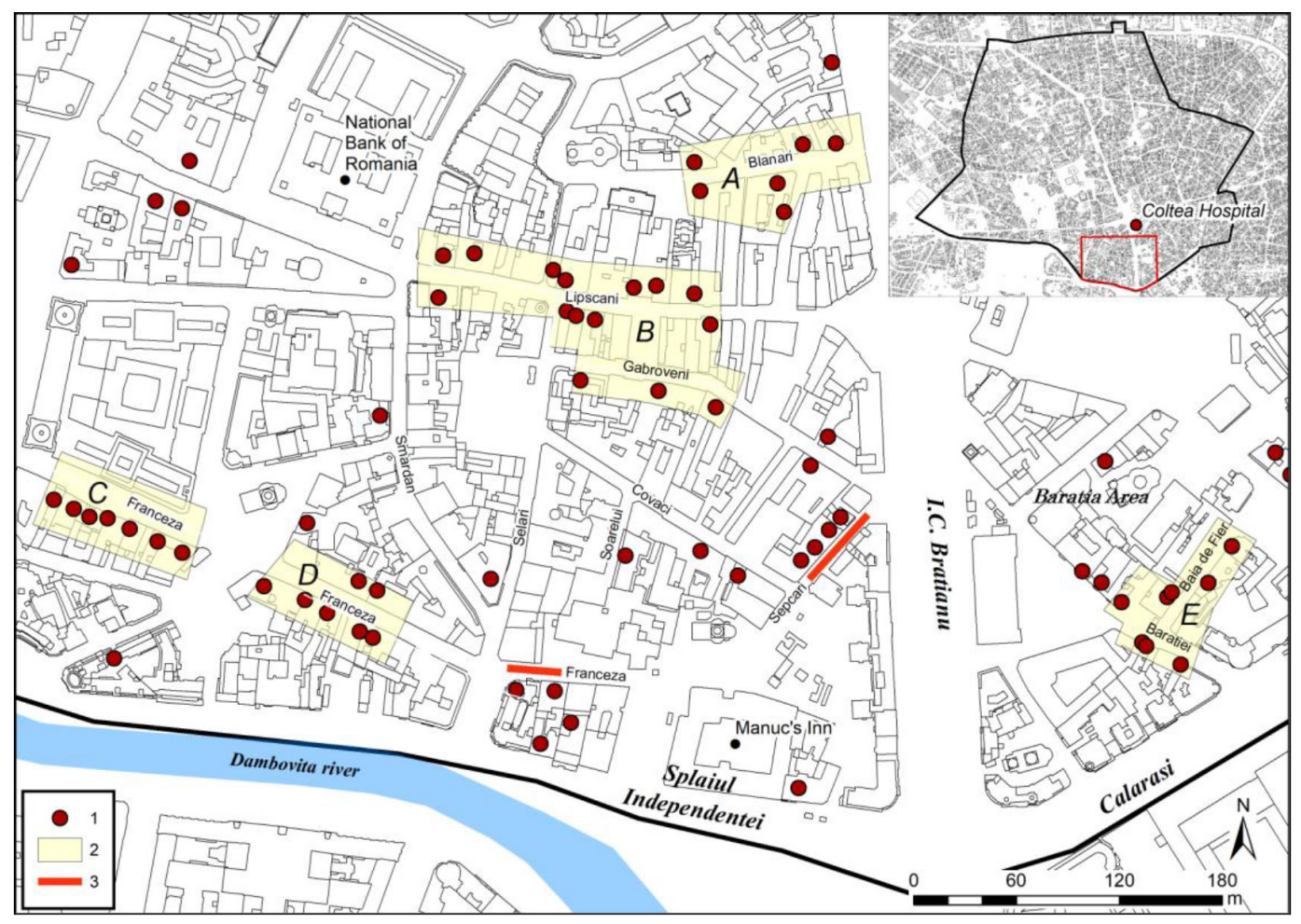

Figure 9. The anticipated spatial effects of building collapse in a similar earthquake to that of March, 1977. (1) Building in the first category of risk (R1); (2) Isolated areas resulting from the hypothesis that all buildings belonging to the R1 class would collapse; (3) Blocked street segments.

These potential blockages are most likely to occur in five areas, identified in Fig. 9 as A, B, C, D, and E. Area A (Blănari area) is small and delimited by building no. 2 (built in 1865, three floors) and the buildings from no. 9 (1880, five floors) to no. 14 (1935, six floors). Area B (LipscaniGabroveni area) is the largest site and contains a group of 15 vulnerable buildings. Possible street blockages could be produced by the collapse of buildings on Lipscani Street, such as no. 26 (1864, five floors) or no. 29 (1934, nine floors) along with no. 76 (1906, four floors), and on Gabroveni Street, such as buildings no. 2 (1940, nine floors) and no. 12 (1924, six floors). Two other areas, C and D, are respectively located on Franceză Street between buildings no. 6 (1869, five floors) and no. 22 (1900, six floors), and between buildings no. 30 (1870, five floors) and no. 42 (1870, five floors). On the west side of the main boulevard, Bulevardul Ion C. Brătianu, area E (Bărăţiei) contains building no. 8 on Baia de Fier Street (1930, five floors) and buildings no. 37 (1870, three floors) and no. 50 (1824, four floors) on Bărătiei Street.

A final consideration is that, for much of the day, the core of the historic centre normally contains between 1000 and 5000 visitors in addition to the area's residents and workers. This only adds to the need to devise proactive earthquake intervention and mitigation strategies.
We therefore suggest the following proactive measures to mitigate the risks associated with a seismic disaster in the city of Bucharest, especially within the core of the city's historic centre:

- the constitution of a technical team of decision makers to identify optimal response strategies for a future earthquake, whose main task would be to identify the critical points and areas for emergency intervention in the most congested areas (Tuns et al., 2013);

- the prioritization of building consolidation, correlated with the buildings' locations and their potential to block street segments and critical access routes in the event of their collapse;

- the re-evaluation of the number and locations of fire stations;

- the development of a system of emergency medical aid posts within the historic centre, taking into account both the area's access problems and the fluctuating population of the area resulting from its entertainment role;

- reorganization of Colţea Hospital, including the expansion of its infrastructure (especially the surgical section, and the number of operating theatres). This hos- 
pital should become the most important point of emergency intervention in the historic centre of Bucharest in the event of a strong earthquake.

\section{Conclusions}

This study demonstrates that GIS can be used effectively as an analytical and decision-making tool in planning for hazard mitigation. GIS, when properly employed, can provide information concerning emergency response accessibility in areas where physical structures are degraded and pose a higher risk of collapse. Such knowledge is critical in anticipating the impact of a disaster. Injury, loss of life, and damage to property can be minimized through more effective and rapid emergency response.

In Europe, Bucharest ranks second, after Istanbul, in its exposure and risk related to earthquakes. It is not enough to be familiar with the distribution of the high-seismic-risk buildings. Emergency intervention is also vital to minimize the consequences of such an event. In order to save lives, knowledge of accessibility levels and related rapid intervention potential is essential in the event of an earthquake. However, the current status and priorities of natural hazard and emergency response planning in the city of Bucharest (and at the national scale) are such that they are unlikely to mitigate the effects of a potential disaster to a sufficient extent. Across several measures - the training of specialists, public awareness and education, infrastructural improvements, and building improvements - current efforts are inadequate.

The passivity of urban decision makers in relation to the very large number of buildings in the highest risk class is perhaps the most surprising element here. These buildings are concentrated in the most populated and attractive areas of the city in terms of leisure and entertainment. Even if Bucharest's inhabitants are partially aware of this risk, the vast majority of tourists are unlikely to realize what could happen should an earthquake occur.

The most recent major disaster event that took place in Bucharest - the fire in Club Colectiv on the night of 30 October 2015, which led to the deaths of 63 people and serious injury to around 150 - brought the major risk that an earthquake can pose to the attention of the local and national authorities. In response, a ban was imposed on all shops, restaurants, and clubs operating in buildings with high seismic risk, but there are not enough resources to refit the high-risk buildings that continue to be inhabited. This event reminded the population and the authorities that an earthquake event or disaster of similar scale will occur again at some point and that it is necessary to have a clearly defined policy that relies upon concrete measures to reduce the human and material losses.

Our study reveals both the importance of accessibility to buildings for emergency intervention and the shortcomings in the current provision of major emergency response services. Our methodology, using simple tools, offers analysts and decision makers a credible means of developing a proactive vision of and a management strategy for emergency response in congested historic areas. GIS is a commonly used tool for analyses of this type, and its results, since they can be expressed cartographically, can be more widely understood than is often the case when other statistical and computational techniques are employed.

Data availability. Lists of technically tested buildings in terms of seismic risk are freely available at http://amccrs.pmb.ro/docs/Lista_ imobilelor_expertizate.pdf (last access: 15 October 2017, Municipality of Bucharest, 2017).

Competing interests. The authors declare that they have no conflict of interest.

Author contributions. CM and II designed the study. GM, CM, and II established and set up the maps. II, CM, RJ, GM, and GP analysed and interpreted the results. II and CM wrote the paper with substantial input from all co-authors. RJ revised the English.

Acknowledgements. This work has been partially supported by the project UB 2008.

Edited by: Sven Fuchs

Reviewed by: two anonymous referees

\section{References}

Alexander, D.: Principles of emergency planning and management, Oxford, Oxford University Press, 2002.

Anhorn, J.: Nepal and the "Urban Resilience Utopia", in: Urban Disaster Resilience and Security, edited by: Fekete A. and Fiedrich, F., The Urban Book Series, Springer, 13-26, https://doi.org/10.1007/978-3-319-68606-6, 2018.

Ardeleanu, L., Leydecker, G., Bonjer, K.-P., Busche, H., Kaiser, D., and Schmitt, T.: Probabilistic seismic hazard map for Romania as a basis for a new building code, Nat. Hazards Earth Syst. Sci., 5, 679-684, https://doi.org/10.5194/nhess-5-679-2005, 2005.

Armaş, I.: Earthquake perception in Bucharest, Romania, Risk Anal., 26, 1223-1234, https://doi.org/10.1111/j.15396924.2006.00810.x, 2006.

Armaş, I. and Avram, E.: Patterns and trends in the perception of seismic risk. Case study: Bucharest Municipality/Romania, Nat. Hazards, 44, 147-161, https://doi.org/10.1007/s11069-0079147-9, 2008.

Armaş, I.: Social vulnerability and seismic risk perception. Case study: the historic centre of the Bucharest Municipality/Romania, Nat. Hazards, 47, 397-410, https://doi.org/10.1007/s11069-008-9229-3, 2008.

Armaş, I.: Multi-criteria vulnerability analysis to earthquake hazard of Bucharest, Romania, Nat. Hazards, 63, 1129-1156, https://doi.org/10.1007/s11069-012-0209-2, 2012. 
Armaş, I., Ionescu, R., Gavriş, A., and Toma-Dănilă, D.: Identifying seismic vulnerability hotspots in Bucharest, Appl. Geogr., 77, 49-63, https://doi.org/10.1016/j.apgeog.2016.10.001, 2016.

Atanasiu, G. M. and Toma, A.-M.: On seismic vulnerability evaluation in dense urban residential areas using spatial information system SIS, Proc. ASTR Annu. Conf. Acad. Tech. Sci. Rom., 114-121, Agir Publishing House, Bucharest, 2012.

Bakillah, M., Domínguez, J., Zipf, A., Liang, S. H. L., and Mostafavi, M. A.: Multi-agent evacuation simulation data model with social considerations for disaster management context, in: Intelligent systems for Crisis management, Geo-information for Disaster Management (Gi4DM), edited by: Zlatanova, S., Peters, R., Dilo, A., and Scholten, H., 3-18, Springer-Verlag, Berlin Heidelberg, 2013.

Bala, A.: Quantitative modelling of seismic site amplification in an earthquake-endangered capital city: Bucharest, Romania, Nat. Hazards, 72, 1429-1445, https://doi.org/10.1007/s11069-0130705-z, 2014

Blandford, J. I., Kumar, S., Luo, W., and MacEachren, A. M.: It's a long, long walk: accessibility to hospitals, maternity and integrated health centres in Niger, Int. J. Health Geogr., 11, 1-15, https://doi.org/10.1186/1476-072X-11-24, 2012.

Boştenaru Dan, M. and Armaş, I.: Earthquake impact on settlements: the role of urban and structural morphology, Nat. Hazards Earth Syst. Sci., 15, 2283-2297, https://doi.org/10.5194/nhess15-2283-2015, 2015.

Boştenaru Dan, M., Armaş I., and Goretti, A.: Earthquake Hazard Impact and Urban Planning - An Introduction, in: Earthquake Hazard Impact and Urban Planning, edited by: Boştenaru Dan, M., Armaş, I., and Goretti, A., 1-14, Springer, Dordrecht, Heidelberg, New York, London, 2014.

Coffee, N., Turner, D., Clark, R. A., Eckert K., Coombe, D., Hugo, G., van Gaan D., Wilkinson, D., Stewar S., and Tonkin, A.: Measuring national accessibility to cardiac services using geographic information systems, Appl. Geogr., 34, 445-455, https://doi.org/10.1016/j.apgeog.2012.01.007, 2012.

Comerio, M. C.: Disaster Recovery and Community Renewal: Housing Approaches, Cityscape: A journal of Policy Development and Research, 16, 51-68, 2014.

Crowley, H., Colombi, M., Pinho, R., Meroni, F., and Cassera, A.: Application of a prioritisation scheme for seismic intervention in school buildings in Italy, in: 14th World Conf. Earthq. Eng. Beijing, China, 12-17, 2008.

Eshghi, K. and Larson, R. C.: Disasters: lessons from the past 105 years, Disaster Prev. Manag., 17, 62-82, 2008.

ESPON TRACC Project: Transport Accessibility at regionallocal scale and patterns in Europe 2013, Applied Research 2013/1/10, Final Report, 274 pp., available at: https://www.espon.eu/sites/default/files/attachments/TRACC_ FR_Volume2_ScientificReport.pdf (last access: 3 March 2016), 2015.

ESPON GROSEE Project: Growth Poles in South-East Europe Emergence of Growth Poles Network in SouthEast of Europe 2013, Applied Research 2013/2/19, Final Report-Scientific Report, 367 pp., available at: https://www.espon.eu/programme/projects/espon-2013/ targeted-analyses/grosee-growth-poles-south-east-europe, (last access: 12 May 2015), 2014.
Fekete, A. and Fiedrich, F.: Introduction to "Urban Disaster Resilience and Security - Adressing Risks in Societies", in: Urban Disaster Resilience and Security, edited by: Fekete A. and Fiedrich F., The Urban Book Series, Springer, 1-12, https://doi.org/10.1007/978-3-319-68606-6_1, 2018.

Fiedrich, F.: An HLA-Based Multiagent System for Optimized Resource Allocation After Strong Earthquakes, Proceedings of the 2006 Winter Simulation Conference, Monterey, CA, USA, 36 December 2006, https://doi.org/10.1109/WSC.2006.323120, 2006.

Geis, D. E.: By design: the disaster resistant and quality of life community, Nat. Hazards Rev., 1, 151-160, https://doi.org/10.1061/(ASCE)1527-6988(2000)1:3(151), 2000.

Goretti, A., Vetta, S., Palmieri, F., Adamo, F., Berlingeri, M., and Palmieri, L.: The Urban System of Crotone, Italy, Facing the Earthquake Impact. in: Earthquake Hazard Impact and Urban Planning, edited by: Boştenaru, D. M., Armaş, I., and Goretti, A., Springer, Dordrecht Heidelberg New York London, 151-170, 2014.

Graeme, H. and Aylward, R.: Using Geographical information system (GIS) to establish access to aged care residential services in non-metropolitan Australia, Proc. 5th Nat. Rural Health Conf., Adelaide, South Australia, available at: http://ruralhealth.org. au/PAPERS/5_gis.pdf $\backslash T 1$ textbackslash\#F (last access: February 2016), 1999.

Grant, D. N., Bommer, J. J., Pinho, R., Michele Calvi, G., Goretti, A., and Meroni, F.: A Prioritization Scheme for Seismic Intervention in School Buildings in Italy, Earthq. Spectra, 23, 291-314, https://doi.org/10.1193/1.2722784, 2007.

Grasso, S. and Maugeri, M.: The road map for seismic risk analysis in a Mediterranean city, Soil Dyn. Earthq. Eng., 29, 1034-1045, https://doi.org/10.1016/j.soildyn.2008.12.001, 2009.

Ianos, I. and Cepoiu, L.: The importance of intraurban structures of the Romanian cities for crisis and emergency situations management, Rom. Rev. Polit. Geogr., 11, 19-29, 2009.

Ianos, I., Sîrodoev, I., Pascariu, G., and Henebry, G.: Divergent patterns of built-up urban space growth following post-socialist changes, Urban Stud., 53, 3172-3188, https://doi.org/10.1177/0042098015608568, 2016.

Ianos, I., Merciu, C., and Sorensen, A.: Incoherence of urban planning policy in Bucharest: Its potential for land use conflict, Land Use Pol., 60, 101-112, https://doi.org/10.1016/j.landusepol.2016.10.030, 2017.

IGFCOT: Cadastral plan of Bucharest Municipality, Institute of Geodesy, Photogrammetry, Cartography and Organization of Territory, 1974-1975.

$\mathrm{Lu}, \mathrm{Y}$. and $\mathrm{Xu}, \mathrm{J}$. : The progress of emergency response and rescue in China: A comparative analysis of Wenchuan and Lushan earthquakes, Nat. Hazards, 74, 421-444, https://doi.org/10.1007/s11069-014-1191-7, 2014.

Lungu, D., Aldea, A., Arion, C., and Baur, M.: Vulnerability of existing building stock in Bucharest, Proc. 6th Intern. Conf. Seismic Zonation, Palm Springs, California, 12-15 November 2000, 837-846, 2000.

Mândrescu, N.: Data Concerning Seismic Risk Evaluation in Romania, Nat. Hazards, 3, 249-259, https://doi.org/10.1007/BF00124580, 1990. 
Mărmureanu, G., Cioflan, C. O., and Mărmureanu, A.: Intensity seismic hazard map of Romania by probabilistic and (neo)deterministic approaches, linear and nonlinear analyses, Rom. Rep. Phys., 63, 226-239, 2011.

Mäntyniemi, P., Mârza, V. I., Kijko, A., and Retief, P.: A new probabilistic seismic hazard analysis for the Vrancea (Romania) seismogenic zone, Nat. Hazards, 29, 371-385, https://doi.org/10.1023/A:1024787621646, 2003.

Momani, N. M. and Salmi, A.: Preparedness of schools in the province of Jeddah to deal with earthquakes risks, Disaster Prev. Manag., 21, 463-473, https://doi.org/10.1108/09653561211256161, 2012.

Municipality of Bucharest: Lists of technically tested buildings in terms of seismic risk, Municipal Administration for Consolidation of Seismic Risk Buildings, Municipality of Bucharest, available at: http://amccrs.pmb.ro/docs/Lista_imobilelor_expertizate. pdf, last access: 15 October 2017.

Naphtali, Z. S.: Delivering health-care services to an urban population, in: GIS for urban environment, edited by: Maantay J. and Ziegler, J., ESRI Press, Redlands, California, 341-347, 2006.

Noto, G.: Combining system dynamics and performance management to support sustainable urban transportation planning, J. Urban Reg. Analysis, IX, 51-71, 2017.

Nushi, B. and van Loenen, B.: The STIG: Framework for the stresstest for infrastructures of geographical information, in: Intelligent systems for Crisis management, Geo-information for Disaster Management (Gi4DM), edited by: Zlatanova, S., Peters, R., Dilo, A., and Scholten, H., Springer-Verlag, Berlin, Heidelberg, 289-298, https://doi.org/10.1007/978-3-642-33218-0_20, 2013.

O'Sullivan, D., Morrison, A., and Shearer, J.: Using desktop GIS for the investigation of accessibility by public transport: an isochrones approach, Int. J. Geogr. Inf. Sci., 14, 85-104, https://doi.org/10.1080/136588100240976, 2000.

Panahi, M., Rezaie, F., and Meshkani, S. A.: Seismic vulnerability assessment of school buildings in Tehran city based on AHP and GIS, Nat. Hazards Earth Syst. Sci., 14, 969-979, https://doi.org/10.5194/nhess-14-969-2014, 2014.

Parker, E. B. and Campbell, J.L.: Measuring access to primary medical care: some examples of the use of geographical information systems, Health Place, 4, 183-193, https://doi.org/10.1016/S1353-8292(98)00010-0, 1998.

Pavel, F., Văcăreanu, R., Ionescu, C., Iancovici, M., and Şercăianu, M.: Investigation of the variability of strong ground motions from Vrancea earthquakes, Nat. Hazards, 74, 1707-1728, https://doi.org/10.1007/s11069-014-1273-6, 2014.

Pavel, F. and Văcăreanu, R.: Assesment of the ground motion levels for the Vrancea (Romania), November 1940 earthquake, Nat. Hazards, 78, 1469-1480, https://doi.org/10.1007/s11069014-1273-6, 2015.

Pollino, M., della Rocca, A. B., Fattoruso G., La Porta L., Lo Curzio S., Arolchi A., James, V., and Pascale, C.: Open Source GIS tools to map earthquake damage scenarios and to support emergency. GEOProcessing: The 4th Intern. Conf. Adv. Geogr. Infor. Sys., Appl. Serv., 152-157, 2012.

Pessina, V. and Meroni, F.: A Web GIS tool for seismic hazard scenarios and risk analysis, Soil Dyn. Earthq. Eng., 29, 1274-1281, https://doi.org/10.1016/j.soildyn.2009.03.001, 2009.

Raffaelle, D., Mezzina, M., and Tosto, A.: Instructions overview on the regional scale analysis of school buildings in Puglia
(Italy), in: ECCOMAS Thematic Conf. Comp. Meth. Struct. Dyn. Earthq. Eng., edited by: Papadrakakis, M., Papadopoulos, V., and Plevris, V., https://doi.org/10.7712/120113.4801.C1239, 2014.

Rufat, S.: Transition post-socialiste et vulnerabilité urbaine à Bucarest, University of Bucharest Publishing House, Bucharest, 2011.

Rufat, S.: Spectroscopy of urban vulnerability, Ann. Assoc. Am. Geogr., 103, 505-525, https://doi.org/10.1080/00045608.2012.702485, 2013.

Salvati, L.: Urban growth and the spatial structure of a changing region: an integrated assessment, J. Urban Reg. Analysis, 6, 514,2014

Schweier, C. and Markus, M.: Classification of collapsed buildings for fast damage and loss Assessment, B. Earthq. Eng., 4, 177192, https://doi.org/10.1007/s10518-006-9005-2, 2006.

Sinha, R., Aditya, K. S. P., and Gupta, A.: GIS-based urban seismic risk assessment using risk, J. Earthq. Tech., 45, 41-63, 2008.

Sotoudehnia, F. and Comber, L.: Measuring perceived accessibility to urban green space: an integration of GIS and participatory map, in: Proc. 14th AGILE Conf. Geogr. Inf.: Adv. Geoinf. Sci. Changing World, available at: https://agile-online.org/conference_paper/cds/agile_2011/ contents/pdf/shortpapers/sp_148.pdf (last access: 2 December 2016), 2011.

Svensson, J.: Accessibility in urban areas for citizens with impairments: using GIS to map and measure accessibility in Swedish cities, in: Universal Design: emerging research and developments, edited by: Maisel, J. L., Bentham Publishing House, New York, 122-131, 2010.

Tatevossian, R. and Albini, P.: Information background of 11th-15th centuries earthquakes located by the current catalogues in Vrancea (Romania), Nat. Hazards, 53, 575-604, https://doi.org/10.1007/s11069-009-9448-2, 2010.

Toma-Dănilă, D.: Transport network vulnerability assessment methodology, based on the cost-distance method and GIS Integration, in: Intelligent systems for Crisis management. Geoinformation for Disaster Management (Gi4DM), edited by: Zlatanova, S., Peters, R., Dilo, A., and Scholten, H., SpringerVerlag, Berlin, Heidelberg, 199-213, 2013.

Török, I.: Assessment of Social Vulnerability to Natural Hazards in Romania, Carpath. J. Earth Env., 12, 549-562, 2017.

Tuns, I., Tămaş, F.-L., and Paşcan, V.: Structural analysis of an existing building on the fulfilment of level of assurance to seismic actions, J. Appl. Eng. Sci., 16, 109-116, 2013.

Vatseva, R., Solakov, D., Tcherkezona, E., Simeonova, S., and Trifonova, P.: Applying GIS in seismic hazard assessment and data integration for disaster management, in: Intelligent systems for Crisis management. Geo-information for Disaster Management (Gi4DM), edited by: Zlatanova, S., Peters, R., Dilo, A., and Scholten, H., Springer-Verlag, Berlin, Heidelberg, 171-183, 2013.

Vojnovic, I., Kotval-K., Z., Lee, J., Ye, M., Ledoux, T., Varnakovida, P., and Messina, J.: Urban built environments, accessibility, and travel behavior in a declining urban core: The extreme conditions of disinvestment and suburbanization in the Detroit region, J. Urban Aff., 36, 225-255, https://doi.org/10.1111/juaf.12031, 2014. 
Waugh, Jr. W. L. and Streib, G.: Collaboration and leadership for effective emergency management, Public Adm. Rev., 66, 131140, 2006.

Wegscheider, S., Schneiderhan, T., Mager, A., Zwenzner, H., Post, J., and Strunz, G.: Rapid mapping in support of emergency response after earthquake events. Nat. Hazards, 68, 181-195, https://doi.org/10.1007/s11069-013-0589-y, 2013.

Weiping, H. and Chi, W.: Urban road network accessibility evaluation method based on GIS spatial analysis techniques, in: Proc. Int. Arch. Photogr., Remote Sens. Spat. Inf. Sci. Conf., 38, 114$117,2011$.
Wiens, M., Schatter, F., Zobel C. W., and Schultmann, F.: Urban Disaster Resilience and Security, edited by: Fekete A. and Fiedrich, F., The Urban Book Series, Springer, 145-168, https://doi.org/10.1007/978-3-319-68606-6, 2018.

Yiannakoulias, N., Bland, W., and Svenson, L. W.: Estimating the effect of turn penalties and traffic congestion on measuring spatial accessibility to primary health care, Appl. Geogr., 39, 172182, https://doi.org/10.1016/j.apgeog.2012.12.003, 2013. 